\title{
Antihyperglycemic and neuroprotective activity of Adenanthera pavonina bark against streptozotocin induced diabetic rats
}

\author{
Alagiri ABARNADEVIKA ${ }^{1 * \mathbb{D}}$, Kumarasamy KAVITHA ${ }^{1} \mathbb{D}$, Kasiramar GOPALASATHEESKUMAR $^{2} \mathbb{D}$ \\ 1 Department of Pharmacology, KMCH College of Pharmacy (Affiliated to Tamil Nadu Dr.M.G.R. Medical \\ University), Coimbatore-641048, Tamil Nadu, India. \\ 2 Department of Pharmacy, Faculty of Engineering and Technology, Annamalai University, Annamalai Nagar- \\ 608002, Tamil Nadu, India. \\ * Corresponding Author. E-mail: abarnadevika@gmail.com (A.A.); Tel. +91-950-049 9400.
}

Received: 22 May 2021 / Revised: 05 August 2021/ Accepted: 05 September 2021

\begin{abstract}
Worldwide diabetes and diabetic neuropathy is the highly prevalent healthcare problem. Herbal based therapy is an alternative and safe management of this problem. Adenanthera pavonina is an important medicinal plant having many of the medicinal values. This research aimed to evaluate the antihyperglycemic and neuroprotective activity of bark of Adenanthera pavonina. Hydro alcohol $(50 \%$ methanol) was used as the solvent for extraction. Streptozotocin $(55 \mathrm{mg} / \mathrm{kg}$, i.p) induced diabetic rats were used for the evaluation of antihyperglycemic and neuroprotective activity. Diabetic rats were treated with hydro alcoholic bark extract of Adenanthera pavonina (HABEA) for 21 days. After treatment period blood glucose levels, SGOT, SGPT, Glutamate and Lipid peroxidase levels were decreased significantly in HABEA (200 and $400 \mathrm{mg} / \mathrm{kg}$, p.o) treated rats. However, body weight, Serotonin, GABA, total protein and reduced glutathione levels were increased. And also behavioral parameter such as pain behavior (Hot Plate Method and Tail Immersion Method) and locomotor behavior (actophotometer) were significantly improved in HABEA (200 and $400 \mathrm{mg} / \mathrm{kg}, \mathrm{p.o})$ treated rats. These are the findings confirms that, the HABEA has significant antihyperglycemic and neuroprotective activity. Alkaloids, glycosides, flavonoids, saponin, phenolics and phytosterol present in the bark of Adenanthera pavonina may be the reason for its antihyperglycemic and neuroprotective activity. Further, this research will useful for the isolation of active principles from HABEA and determining its molecular mechanisms.
\end{abstract}

KEYWORDS: Diabetes; glutamate; behavioral; herbal medicine; diabetic neuropathy.

\section{INTRODUCTION}

Diabetes is a metabolic problem of multiple etiologies categorized by prolonged hyper-glycaemia resultant from failings in insulin production, insulin activity, or both [1]. Diabetic patients are predisposed to many problems associated with their disease and most prevalent problems in diabetes are diabetic neuropathy which affects about $50 \%$ of diabetic patients [2]. Diabetic neuropathy distresses pain fibres and motor neurons, causing foot ulcers otherwise damage. This damage is prominent to amputation in excess of $80 \%$ of cases [3]. Numerous pathways inventing from diabetes prompt oxidative stress causing diabetic neuropathy and formation of polyol pathway initiation, aldol reductase initiation, AGEs (advanced glycation end products) and initiation of PKC (protein kinase C) [4]. Due to its multifactorial nature, management of this problem is difficult and treatment options are limited. This has led to increased exploration of alternative drugs from natural sources, having potent antidiabetic as well as neuroprotective activity. Adenanthera pavonina (AP) is an important medicinal plant widely distributed in Asia and America. Various parts of AP are traditionally used for the management of various health illnesses such as boils, inflammations, arthritis, rheumatism, blood disorders, cholera, epilepsy, convulsion, paralysis, spasm, indigestion, pulmonary infection, chronic rheumatism, gout, haematuria, haematemesis, ulcer and diarrhea [5]. And also bark of AP have been scientifically evaluated for its anti-inflammatory [6], anticancer [7], antibacterial [8], antifungal [9], anthelmintic [10], antioxidant [11] and antihyperlipidemic activities [12]. The bark of AP contains the secondary metabolites including alkaloids, glycosides, flavonoids, saponin,

How to cite this article: Abarnadevika A, Kavitha K, Gopalasatheeskumar K. Antihyperglycemic and neuroprotective activity of Adenanthera pavonina bark against streptozotocin induced diabetic rats. J Res Pharm. 2022; 26(1): 145-153. 
phenolics, phytosterol, tannins and terpenoids [13]. Commonly alkaloids, flavonoids and phenolics are associated with anti hyperglycemic activity as well as neuroprotective activity $[14,15,16]$. However, there is no scientific validation for antihyperglycemic and neuroprotective activities of AP bark extract. So that, this research was aimed to evaluate the anti hyperglycemic and neuroprotective activity of AP bark extract using streptozotocin (STZ) persuaded diabetic rats.

\section{RESULTS}

The body weight of the normal and diabetic rats are shown in Table 1.

Table 1. Effect of HABEA on body weight levels in normal and diabetic rats.

\begin{tabular}{|c|c|c|c|c|c|}
\hline \multirow[b]{2}{*}{ Groups } & \multicolumn{5}{|c|}{ Body weight (g) } \\
\hline & $\begin{array}{c}\text { Before } \\
\text { induction }\end{array}$ & $\begin{array}{l}1^{\text {st }} \text { day } \\
\text { treatment }\end{array}$ & $\begin{array}{c}7^{\text {th }} \text { day } \\
\text { treatment }\end{array}$ & $\begin{array}{l}14^{\text {th }} \text { day } \\
\text { treatment }\end{array}$ & $\begin{array}{c}21^{\text {ndday }} \\
\text { treatment }\end{array}$ \\
\hline Normal & $164.66 \pm 13.77$ & $165.33 \pm 13.38$ & $164.66 \pm 12.99$ & $165.66 \pm 13.77$ & $168.33 \pm 13.64$ \\
\hline Control & $168.33 \pm 3.38$ & $145.66 \pm 7.623^{\#}$ & $140.66 \pm 7.51^{\#}$ & $130.33 \pm 5.78^{\# \#}$ & $115.66 \pm 5.78^{\# \# \#}$ \\
\hline Standard & $152 \pm 4.61$ & $146.33 \pm 6.88$ & $150.33 \pm 4.09$ & $156 \pm 3.78^{*}$ & $159 \pm 3.78^{* * *}$ \\
\hline Low dose & $171.66 \pm 3.75$ & $153.33 \pm 2.91$ & $159.66 \pm 0.88$ & $177.66 \pm 12.25^{* * *}$ & $180.66 \pm 12.44^{* * *}$ \\
\hline High dose & $154 \pm 2.64$ & $122 \pm 211$ & $135.66 \pm 1.212$ & $143 \pm 3.215^{* *}$ & $161 \pm 7.230^{* * *}$ \\
\hline
\end{tabular}

The body weights of diabetic control rats and all the treatments rats were significantly lower than that of normal group rats at first day of treatment. At the 21st day, the body weights of Metformin $(65 \mathrm{mg} / \mathrm{kg}$, p.o) and hydro alcoholic bark extract of Adenanthera pavonina (HABEA) 200 and $400 \mathrm{mg} / \mathrm{kg}$, p.o., treated rats were significantly increased when compared with diabetic control rats. Previous studies reported that, decreased body weight is due to muscle degeneration in diabetic rats [17]. The increased body weight treatment groups may be the reason for prevention of muscle wasting in diabetic rats. The blood glucose levels of the normal and diabetic rats are shown in Figure 1.

\section{Blood glucose}

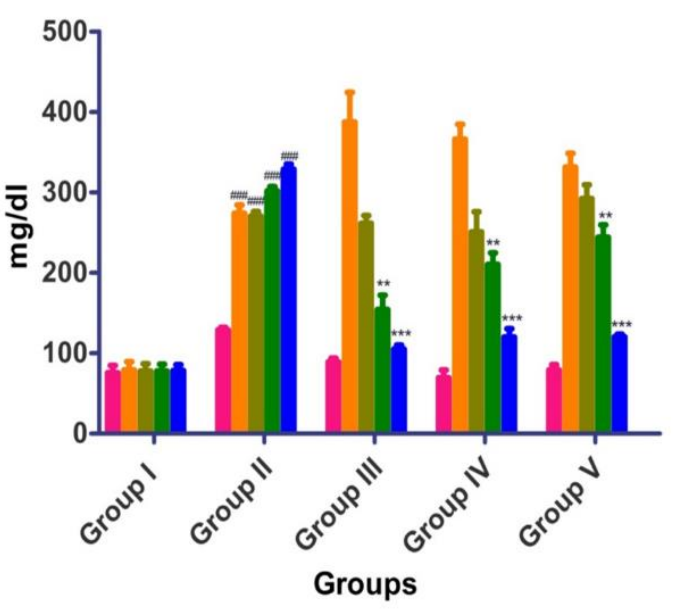

Before Induction

1st day treatment

7 th day treatment

14th day treatment

21nd day treatment

Figure 1. Effect of HABEA on blood glucose levels in normal and diabetic rats. Data is expressed as mean \pm SEM, $\mathrm{n}=6$, One way ANOVA followed by Dunnett's test Compared with normal; \# $\mathrm{p}<0.05$, \#\# $\mathrm{p}<0.01$, \#\#\# $\mathrm{p}<0.001$, Compared with Disease control; ${ }^{*} \mathrm{p}<0.05,{ }^{* *} \mathrm{p}<0.01,{ }^{* * *} \mathrm{p}<0.001$.

The blood glucose levels of diabetic control rats and all the treatments rats were significantly increased when compared with normal group rats at first day of treatment. At the 21st day, the blood glucose levels were significantly declined in Metformin $(65 \mathrm{mg} / \mathrm{kg}$, p.o) and HABEA (200 and $400 \mathrm{mg} / \mathrm{kg}$, p.o) treated rats. The increased in serum glucose levels due to diabetes induced by STZ [18]. The decreased of blood glucose level maybe the reason of anti-hyperglycemic effect of HABEA. Hemoglobin, Glycosylated hemoglobin (HbA1C), SGOT and SGPT levels in normal and diabetic rats are shown in Table 2. 
Table 2. Effect of HABEA on Hemoglobin, Glycosylated hemoglobin, SGOT and SGPT levels in normal and diabetic rats.

\begin{tabular}{ccccc}
\hline Groups & $\begin{array}{c}\text { Hemoglobin } \\
(\mathrm{g} / \mathrm{dl})\end{array}$ & HbA1C $(\%)$ & SGOT (U/L) & SGPT (U/L) \\
\hline Normal & $15.05 \pm 0.050$ & $5.04 \pm 0.33$ & $128.50 \pm 3.5$ & $60.50 \pm 3.5$ \\
Control & $8.95 \pm 0.280 \# \# \#$ & $7.185 \pm 0.035 \# \#$ & $285.5 \pm 12.5$ \#\# & $188 \pm 20$ \#\#\# \\
Standard & $12.025 \pm 0.055^{* *}$ & $6.165 \pm 0.065^{*}$ & $133.00 \pm 3.00^{* *}$ & $80.00 \pm 4^{* *}$ \\
Low dose & $12.025 \pm 0.055^{*}$ & $6.805 \pm 0.175$ & $190.01 \pm 9.00^{*}$ & $117.5 \pm 2.5^{* *}$ \\
High dose & $11.88 \pm 0.600^{* *}$ & $6.805 \pm 0.175^{*}$ & $121 \pm 21.00^{* *}$ & $98.00 \pm 4^{* *}$
\end{tabular}

Data is expressed as mean \pm SEM, n=6, One way ANOVA followed by Dunnett's test Compared with normal; \# $\mathrm{p}<0.05$, \#\# p<0.01, \#\#\# p<0.001, Compared with Disease control; ${ }^{*} \mathrm{p}<0.05,{ }^{* *} \mathrm{p}<0.01,{ }^{* * *} \mathrm{p}<0.001$.

The hemoglobin levels in diabetic control group were significantly declined when compared with normal group. Metformin (65 mg/kg, p.o) and HABEA (200 and $400 \mathrm{mg} / \mathrm{kg}$, p.o) treated rats were significantly increased the hemoglobin levels. Consequently Glycosylated hemoglobin levels were significantly increased in diabetic rats and declined in Metformin $(65 \mathrm{mg} / \mathrm{kg}$, p.o) and HABEA (200 and 400 $\mathrm{mg} / \mathrm{kg}$, p.o) treated diabetic rats. The extreme glucose present in the blood bound to the hemoglobin so that hemoglobin level was decreased in diabetic rats. Glycosylated hemoglobin was increased in diabetic rats due to the non-enzymatic reaction between glucose and free amino groups of haemoglobin [19].

The SGOT and SGPT levels were significantly increased in diabetic control group when compared with normal group. These elevated levels were significantly declined in Metformin $(65 \mathrm{mg} / \mathrm{kg}$, p.o) and HABEA (200 and $400 \mathrm{mg} / \mathrm{kg}$, p.o) treated diabetic rats. Increased levels of SGOT and SGPT are a common indication of liver illness [20]. In STZ induced diabetic rats, the leakage of SGOT and SGPT enzymes from liver to blood stream consequently of the hepatotoxic outcome of STZ. The behavioral parameters of the normal and diabetic rats are shown in Figure 2.

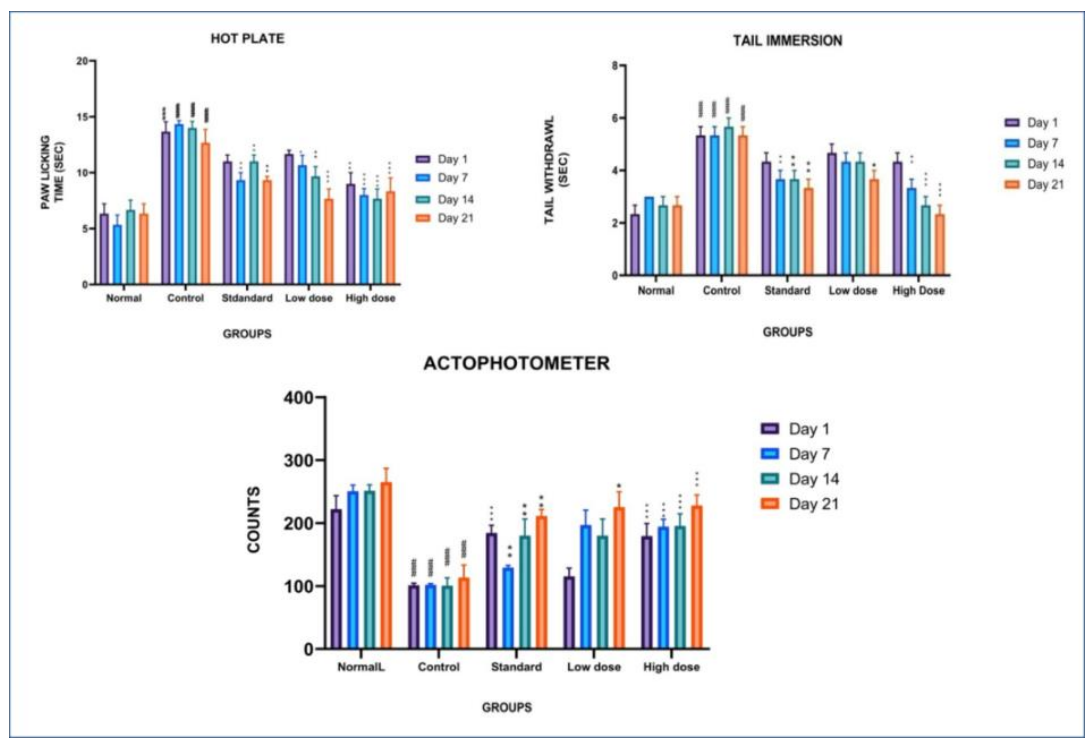

Figure 2. Effect of HABEA on behavioral parameters of the normal and diabetic rats. Data is expressed as mean \pm SEM, $n=6$, One way ANOVA followed by Dunnett's test Compared with normal; \# $\mathrm{p}<0.05$, \#\# $\mathrm{p}<0.01$, \#\#\# $\mathrm{p}<0.001$, Compared with Disease control; $\mathrm{p}<0.05,{ }^{* *} \mathrm{p}<0.01$, ${ }^{* * *} \mathrm{p}<0.001$

Paw licking time (Hot plate method) and tail withdrawal time (Tail immersion method) in all the treatment groups except normal control rats were significantly increased in 1st day of treatment. At the 21st day, the rats treated with Metformin (65 mg/kg, p.o) and HABEA (200 and $400 \mathrm{mg} / \mathrm{kg}$, p.o) were decreased the paw licking time and tail withdrawal time when compared with STZ diabetic rats. Diabetic neuropathy distresses the peripheral nerves such as motor neurons and pain fibres [21]. The higher response time in hot plate and tail immersion method in diabetic rats is due to the loss of pain perception caused by nerve damage [22]. The declined response time in hot plate and tail immersion method in Metformin $(65 \mathrm{mg} / \mathrm{kg}$, 
p.o) and HABEA (200 and $400 \mathrm{mg} / \mathrm{kg}$, p.o) treated rats may due to prevention of nerve damage followed by pain perception.

The locomotor activity (Actophotometer) counts were significantly decreased in all the group of diabetic rats except normal rats on 1st day of treatment. At the 21st day of treatment period Metformin (65 $\mathrm{mg} / \mathrm{kg}$, p.o) and HABEA (200 and $400 \mathrm{mg} / \mathrm{kg}$, p.o) treated rats were significantly increased the locomotor activity when compared to diabetic control rats. The decreased locomotor activity is due to the neuronal damage caused by STZ. The increased locomotor activity is due to the neuroprotective effect of HABEA. The neurotransmitter (Glutamate, serotonin and GABA) levels of the normal and diabetic rats are shown in Figure 3.

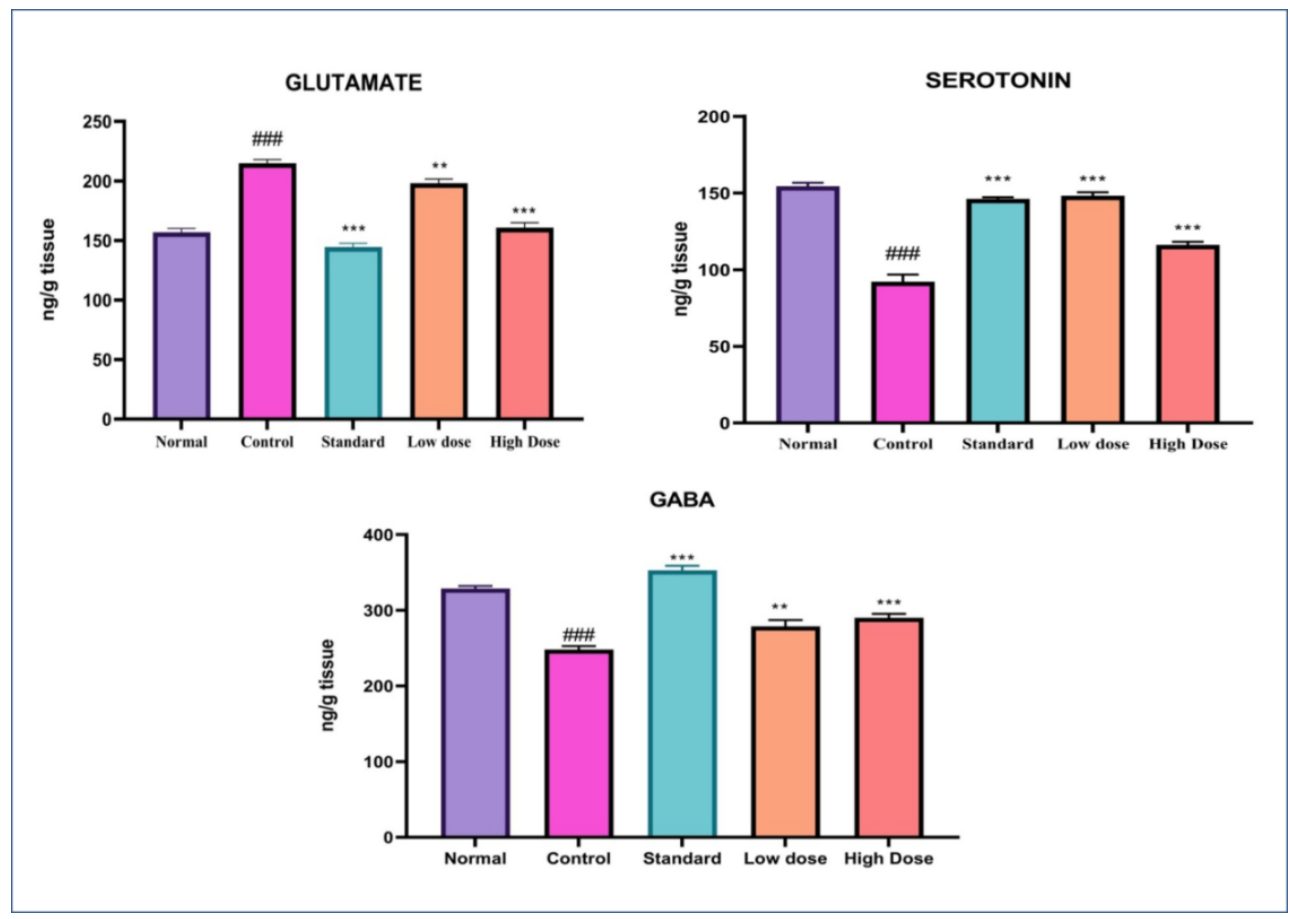

Figure 3. Effect of HABEA on Glutamate, Serotonin, GABA of the normal and diabetic rats. Data is expressed as mean $\pm \mathrm{SEM}, \mathrm{n}=6$, One way ANOVA followed by Dunnett's test Compared with normal; \# $\mathrm{p}<0.05$, \#\# $\mathrm{p}<0.01$, \#\#\# $\mathrm{p}<0.001$, Compared with Disease control; ${ }^{*} \mathrm{p}<0.05,{ }^{* *} \mathrm{p}<0.01,{ }^{* * *} \mathrm{p}<0.001$

The serotonin and GABA levels were significantly decreased in diabetic control rats when compared with normal group rats. However, Glutamate levels were increased in diabetic control rats. Treatment with Metformin (65 mg/kg, p.o) and HABEA (200 and $400 \mathrm{mg} / \mathrm{kg}$, p.o) rats shows significant increased levels of serotonin and GABA and also Glutamate were decreased when compared with diabetic control rats. The serotonin and GABA are the neurotransmitters that acts chief role in nerve pathways in the brain [23, 24]. These neurotransmitters are accountable for cognitive mechanisms. The increased levels of HABEA (200 and $400 \mathrm{mg} / \mathrm{kg}$, p.o) is due to the neuroprotective activity of HABEA. Additional release of glutamate can lead to excite-toxic injuries in the brain due to the epilepsy, ischemia and neurodegenerative diseases [25]. Decreased levels of glutamate levels confirm the neuroprotective activity of HABEA against STZ induced diabetic rats. The antioxidant levels of the normal and diabetic rats are shown in Table 3.

Table 3. Effect of HABEA on Total Protein, GSH and LPO levels in liver and brain.

\begin{tabular}{|c|c|c|c|c|c|c|}
\hline \multirow[t]{2}{*}{ Groups } & \multicolumn{2}{|c|}{ Total protein (mg/dl) } & \multicolumn{2}{|c|}{ GSH (mM/mg of tissue extract) } & \multicolumn{2}{|c|}{$\begin{array}{c}\text { LPO (nMoles of MDA released/ } \\
\text { mg protein) }\end{array}$} \\
\hline & Liver & Brain & Liver & Brain & Liver & Brain \\
\hline Normal & $4.660 \pm 0.267$ & $3.237 \pm 0.0142$ & $9.303 \pm 0.0303$ & $6.852 \pm 0.0242$ & $1.257 \pm 0.120$ & $5.56 \pm 0.124$ \\
\hline Control & $8.117 \pm 0.505^{\# \# \# ~}$ & $5.328 \pm 0.0741^{\# \# \#}$ & $3.973 \pm 0.142^{\# \# \# ~}$ & $2.541 \pm 0.0214^{\# \# \#}$ & $7.697 \pm 0.283^{\# \# \# ~}$ & $12.025 \pm 0.0158^{\# \# \# ~}$ \\
\hline Standard & $6.233 \pm 0.184^{* * *}$ & $3.025 \pm 0.0147^{* * *}$ & $8.287 \pm 0.318^{* * *}$ & $5.0214 \pm 0.0180^{* * *}$ & $4.303 \pm 0.334^{* \star *}$ & $6.54 \pm 0.0587^{* * *}$ \\
\hline Low dose & $7.050 \pm 0.095^{* * *}$ & $5.201 \pm 0.014^{* *}$ & $6.400 \pm 0.488^{* * *}$ & $3.248 \pm 0.0641^{* * *}$ & $6.083 \pm 0.073^{* *}$ & $12.010 \pm 0.01120^{* *}$ \\
\hline High dose & $6.70 \pm 0.0370^{* * *}$ & $3.582 \pm 0.0245^{* * *}$ & $7.190 \pm 0.0310^{* * *}$ & $4.365 \pm 0.013^{* * *}$ & $5.063 \pm 0.31^{* * *}$ & $7.32 \pm 0.14^{* * *}$ \\
\hline
\end{tabular}

Data is expressed as mean \pm SEM, $n=6$, One way ANOVA followed by Dunnett's test Compared with normal; \# $\mathrm{p}<0.05$, \#\# $\mathrm{p}<0.01$, \#\#\# $\mathrm{p}<0.001$, Compared with Disease control;* $\mathrm{p}<0.05$, $^{* *} \mathrm{p}<0.01,{ }^{* * *} \mathrm{p}<0.001$. 
The GSH levels were significantly decreased in liver and brain of diabetic control rats when compared with normal group rats. However, total protein and lipid peroxides (LPO) levels were increased in liver and brain of diabetic control rats. Treatment with Metformin $(65 \mathrm{mg} / \mathrm{kg}, \mathrm{p} . \mathrm{o})$ and HABEA (200 and $400 \mathrm{mg} / \mathrm{kg}$, p.o) rats shows significant increased levels of GSH, and decreased levels of total protein and LPO when compared with diabetic control rats. GSH is one of the major scavenging enzymes that remove toxic free radicals and play important role in protecting the cell against the potentially deleterious effects of reactive oxygen species [26].

\section{CONCLUSION}

Results of this study confirm the anti-hyperglycemic and neuroprotective effects of hydroalcholic bark extract of Adenanthera pavonina. Further studies needed to elucidate the mechanism of action and identification of active principles.

\section{MATERIALS AND METHODS}

\subsection{Materials}

The bark of AP was collected from Kalapatti road sides, Coimbatore district, Tamil Nadu, India on January 2019. STZ, metformin were purchased from Sigma Aldrich, USA. Chloroform, methanol was obtained from SD Fine Chemicals Pvt. Ltd, Mumbai, India. Ketamine hydrochloride was obtained from $\mathrm{KMCH}$ Pharmacy, Coimbatore. The experimental animals were procured from Sri Venkateshwara Enterprises, Bangalore, India. EDTA, HCl- heptane potassium phosphate buffer $\mathrm{pH}$ 7.2, Serotonin, Glutamate, Tris-HCl buffer, n- Butanol, copper sulphate, carbonate-bicarbonate buffer, $\mathrm{pH}$ 9.95, copper tartarate reagent, Folin's reagent, Trichloro acetic acid (TCA), Ellman's reagent, Glutathione reduced, sodium dodecyl sulfate, acetic acid, thiobarbituric acid and 1,1,3,3 - tetraethoxy propane were procured from Merck (India) Ltd., Mumbai. SGOT and SGPT kits were purchached from Span diagnostics, Surat, India.

\subsection{Preparation of plant material and extraction}

The plant was authenticated by Botanical survey of India (BSI), Southern circle, Coimbatore, Tamil Nadu (No. BSI/SRC/5/23/2019/Tech/3011). The collected bark material was washed with distilled water, dried under sunshade in dark room, powdered by using mechanical mixer and sieved under sieve No. 40 and sieve No.20. The powdered material was macerated in hydroalcohol (50\% methanol) for 15 days. Then the extract was filtered with whatman no. 1 filter paper. The obtained extract was concentrated distillation at $45^{\circ} \mathrm{C}$ and stored in air tight glass container at $4^{\circ} \mathrm{C}$ [27].

\subsection{Experimental animals}

About 30 Male Sprague Dawley rats (age: 6 months, weigt: $180 \pm 20$ g) were purchased from Biogenlaboratory animal facility, Bangalore. The rats were housed in clean polypropylene cages and maintained under room temperature $\left(27 \pm 2^{\circ} \mathrm{C}\right)$ with $12 \mathrm{~h}$ light and $12 \mathrm{~h}$ dark cycle. The rats were given standard pellets diet and water ad libitum throughout the experimental period. The animal ethical was getting from institutional animal ethics committee of $\mathrm{KMCH}$ College of Pharmacy (Approval No. KMCH/M.Pharm/10/2019-20).

\subsection{Grouping of animals}

The rats were divided into five groups, six rats in each group and treated as below and The doses for HABEA were selected as per the literature [40]:

- Group I: Normal control rats received vehicle solution (normal saline) for 21 days.

- Group II: Diabetic control rats injected with STZ $(55 \mathrm{mg} / \mathrm{kg}$, i.p) at the day of induction and received vehicle solution (normal saline) for 21 days.

- Group III: Standard group rats injected with STZ (55 mg/ $\mathrm{kg}$, i.p) at the day of induction and received Metformin (65 mg/kg, p.o) for 21 days.

- Group IV: Low dose group rats injected with STZ $(55 \mathrm{mg} / \mathrm{kg}$, i.p) at the day of induction and received HABEA (200 mg/kg, p.o) for 21 days.

- Group V: High dose group rats injected with STZ $(55 \mathrm{mg} / \mathrm{kg}$, i.p) at the day of induction and received HABEA ( $400 \mathrm{mg} / \mathrm{kg}$, p.o) for 21 days. 


\subsection{Experimental induction of diabetes}

The all group rats except group I were fasted overnight and diabetes was induced by a single injection of a freshly prepared solution of STZ ( $55 \mathrm{mg} / \mathrm{kg}$, i.p). After 72 hour of induction, all the rats were checked for its glucose level using AccuCheck glucometer. The rats were considered as diabetic, if their blood glucose values above $250 \mathrm{mg} / \mathrm{dl}$. After 7 days of stabilization, the plant extracts and standard drugs were given to respective groups for 21 days [2].

\subsection{Estimation of body weight and blood glucose levels}

The body weight and blood glucose levels of each group of animals were estimated at the 1 th day, 7 th day, 14th day and 21st day of treatment. The blood was collected at tail tip for the estimation of blood glucose levels and estimated using AccuCheck glucometer.

\subsection{Estimation of behavioral changes}

Behavioural changes were estimated at 1th day, 7th day, 14th day and 21st day of treatment using pain behavior method (Hot plate method and tail immersion method) and locomotor behavior method (Actophotometer test).

\subsubsection{Hot plate method}

Eddy's hot plate was used for the hot plate method. About $50-55^{\circ} \mathrm{C}$ were maintained in hot plate. Each animal were placed in the hot plate and observed the paw licking response time and 10 seconds was cut- off time. The reaction time was noted after the oral administration of the drugs and test compounds. The responses were recorded $30 \mathrm{~min}$ after administration of standard and plant extracts [28].

\subsubsection{Tail immersion method}

Tail immersion was performed through immersing tail in hot water $\left(52.5 \pm 2^{\circ} \mathrm{C}\right)$. The tail withdrawal times were recorded and 15 seconds was cut- off time. After recording, the tail of rats was sensibly dried. The responses were recorded $30 \mathrm{~min}$ after administration of standard and plant extracts [29].

\subsubsection{Locomotor behavior method}

Actophotometer was used for the testing of locomotor behavior of each rat. Animals were hired in Actophotometer. The counts were documented for $5 \mathrm{~min}$ in all animals. Each animal was treated with respective drug and activity score was recorded after $30 \mathrm{~min}$ Decreased activity score was taken as index of CNS depression. The responses were recorded $30 \mathrm{~min}$ after administration of standard and plant extracts [30].

\subsection{Estimation of serum biochemical parameters and hematological parameters}

At the end of the treatment period of 21 days, the blood samples were collected from retro orbital sinus using centrifugation tubes contains EDTA for hematological analysis and without EDTA for serum biochemical estimation. The hematological parameters such as hemoglobin and HbA1C were estimated using standard methods described by Nayak and Pattabiraman [31], Reitmann and Franke [32]. The serum was isolated from blood using centrifugation method. And serum SGOT and SGPT were estimated using standard enzymatic kits.

\subsection{Estimation of neurotransmitters}

At the end of the experimental period, all the rats were euthanized using ketamine hydrochloride $\left(87 \mathrm{mg} / \mathrm{kg}\right.$, ip) and the brain tissues were excised at $0^{\circ} \mathrm{C}$. The $5 \%$ brain homogenate was prepared with $\mathrm{HCl}-$ heptane potassium phosphate buffer $\mathrm{pH}$ 7.2, centrifuged at $2000 \mathrm{rpm}$ for $10 \mathrm{~min}$ and the supernatant was used for the estimation of GABA, Glutamate and Serotonin levels.

\subsubsection{Estimation of glutamate}

About $1.4 \mathrm{ml}$ of sample were added with $1.75 \mathrm{ml}$ of OPT reagent and heated at $100^{\circ} \mathrm{C}$ for $10 \mathrm{~min}$. After fluorophore development, readings were measured at $515 \mathrm{~nm}$ using spectrofluorimeter. Glutamate was used as standard. 


\subsubsection{Estimation of serotonin}

About $1.4 \mathrm{ml}$ of sample were added with $1.75 \mathrm{ml}$ of OPT reagent and heated at $100^{\circ} \mathrm{C}$ for $10 \mathrm{~min}$. After fluorophore development, readings were measured at 360-470 $\mathrm{nm}$ using spectrofluorimeter. Serotonin was used as standard [33].

\subsubsection{Estimation of brain GABA content}

About $0.1 \mathrm{~mL}$ of sample was added with $0.2 \mathrm{ml}$ of $0.14 \mathrm{M}$ ninhydrin (Prepared with $0.5 \mathrm{M}$ carbonatebicarbonate buffer, $\mathrm{pH}$ 9.95). This mixture was heated for $30 \mathrm{~min}$ at $60^{\circ} \mathrm{C}$. After heating, the mixture was allowed to cool and $5 \mathrm{ml}$ of copper tartarate reagent was added. Then the fluorescence was measured at $377 / 455 \mathrm{~nm}$ in a spectofluorimeter after 10min [34].

\subsection{Estimation of antioxidant parameters}

After treatment period, the rats were euthanized using ketamine hydrochloride $(87 \mathrm{mg} / \mathrm{kg}$, ip), liver and brain of rats were isolated and washed with normal saline. The separated liver and brain was homogenized with $0.1 \mathrm{M}$ Tris- $\mathrm{HCl}$ buffer ( $\mathrm{pH}$ 7.4) and $\mathrm{n}$ - Butanol buffer using Teflon coated homogenizer. The homogenate was centrifuged for $10 \mathrm{~min}$ at $10000 \mathrm{rpm}$. The supernatant was collected and used for the estimation of total protein, Reduced Glutathione (GSH) and Lipid peroxidase levels.

\subsubsection{Estimation of total protein}

Total protein was estimated using Lowry method [35]. About $0.1 \mathrm{ml}$ of sample was added with $0.9 \mathrm{ml}$ of water and $4.5 \mathrm{ml}$ of copper sulphate. The mixture was added with $0.5 \mathrm{ml}$ of Folin's reagent after $10 \mathrm{~min}$ at room temperature. The blue color was formed after $20 \mathrm{~min}$, and measured at $640 \mathrm{~nm}$ using spectrophotometer.

\subsubsection{Estimation of GSH}

GSH was measured using Ellman's procedure [36]. About $250 \mu \mathrm{l}$ of tissue homogenate was added with $1 \mathrm{ml}$ of $5 \%$ TCA and centrifuged for $10 \mathrm{~min}$ at $3000 \mathrm{rpm}$. The supernatant was added with $1.5 \mathrm{ml}$ of 0.2 $\mathrm{M}$ phosphate buffer and $250 \mu \mathrm{l}$ of $0.6 \mathrm{mM}$ Ellman's reagent. The values were analyzed at $412 \mathrm{~nm}$. Glutathione reduced was uses as standard [37].

\subsubsection{Estimation of LPO}

Lipid peroxidation levels were measured using Okhawa et al. [38], method. About $1 \mathrm{ml}$ of tissue homogenate were added with $4 \%(\mathrm{w} / \mathrm{v})$ sodium dodecyl sulfate, $20 \%$ acetic acid (prepared in $0.27 \mathrm{M}$ hydrochloric acid, $\mathrm{pH} 3.5$ ) and $0.8 \%$ thiobarbituric acid, $\mathrm{pH} 7.4$ and heated for $1 \mathrm{~h}$ at $85^{\circ} \mathrm{C}$. The pink color was formed and measured at $532 \mathrm{~nm}$. The 1,1,3,3 - tetraethoxy propane was used as the standard [39].

\subsection{Statistical analysis}

The data obtained from the results were analyzed by using one way ANOVA test using graph pad prism software. All data were expressed as the mean SEM of their parameter.

Author contributions: Concept - A.A., K.K.; Design - K.K., K.G.; Supervision - A.A.; Resources - A.A., K.K.; Materials - K.K., K.G.; Data Collection and/or Processing - K.K., K.G; Analysis and/or Interpretation - K.K., K.G., A.A.; Literature Search - K.K, A.A.; Writing - K.G.; Critical Reviews - K.K., A.A., K.G.

Conflict of interest statement: The authors declared no conflict of interest.

Ethics committee approval: Experimental studies were approved by IAEC with registration number of 685/OPO/Re/S/A/CPCSEA (IAEC No. KMCRET/M.Pharm/10/2019-20).

\section{REFERENCES}

[1] Maitra Abbas AK. Endocrine system. Robbins and Cotran Pathologic basis of disease (7thedtn). Saunders. Philadelphia. 2009; 200:1156-1226.

[2] Hajira BH, Anita M. Antihyperglycemic and neuroprotective effects of Wattakaka volubilis (L.f.) Stapf root against streptozotocin induced diabetes. Braz J Pharm Sci. 2016; 52(3):413-424. [CrossRef] 
[3] Boulton AJ, Vinik AI, Arezzo JC, Bril V et al. American diabetes association, Diabetic neuropathies: a statement by the American Diabetes Association. Diab care. 2005; 28(4): 956-962. [CrossRef]

[4] Roy B. Biomolecular basis of the role of diabetes mellitus in osteoporosis and bone fractures. World J Diabetes. 2013; 15(4):101-113. [CrossRef]

[5] Maurycyo SG, Roberta CM, Hugo LMB et al. Advances in the research of Adenanthera pavonina: From traditional use to intellectual property. J Med Plant Res. 2020; 14(1): 24-53. [CrossRef]

[6] Ara A, Arifuzzaman M, Ghosh CK et al. Anti-inflammatory activity of Adenanthera pavonina L., Fabaceae, in experimental animals. Rev Bras Farmacogn. 2010; 20: 929-932. [CrossRef]

[7] Lindamulage IKS, Soysa P. Evaluation of anticancer properties of a decoction containing Adenanthera pavonina L. and Thespesia populnea L. BMC Complement Altern Med. 2016; 16: 1-8.

[8] Hussain A, Rizvi A, Wahab S, Zareen I, Ansari, S, Hussain MS. Antibacterial screening of the bark of Adenanthera pavonina (L.). Int J Biomed Res. 2011; 2: 110-122. [CrossRef]

[9] Rodrigo SK, Jayasinghe ULB, Bandara BMR. Antifungal, Antioxidant and cytotoxic activity of Acronychia pedunculata and Adenanthera pavonina. Peradeniya University Research Sessions-Sri Lanka. 2007; 12: $94-95$.

[10] Dash S, Das C, Sahoo DC. Phytochemical and anthelmintic screening of crude bark extract of Adenanthera pavonina Linn. Pharmacie Globale: IJCP. 2010; 1: 1-4.

[11] Ara A, Msaleh-E-In MM, Ahmed NU, Ahmed M, Abul Hashem M, Bachar SC. Phytochemical Screening, Analgesic, Antimicrobial and Antioxidant Activities of Bark Extracts of Adenanthera pavonina L. (Fabaceae). Adv Appl Sci Res. 2010; 4: 352-360.

[12] Das S, Dash S, Sahoo AC, Giri RK, Sahoo DC, Guru P. Antihyperlipidemic activity of Adenanthera pavonina Linn. ethanolic bark extract fractions. Nature of Pharmaceutical Technology. 2011; 1: 1-4.

[13] Arshad H, Sarfaraj HM, Aliza R, Shadma W. Pharmacognostical Standardization of Stem Bark of Adenanthera pavonina L. Pharmacogn J. 2010; 2: 240-246. [CrossRef]

[14] Firdous SM. Phytochemicals for treatment of diabetes. EXCLI J. 2014; 6(13): 451-453.

[15] Patrick EA, Isaac UA. Mechanisms of actions of some bioactive anti-diabetic principles from phytochemicals of medicinal plants: A review. Indian J Nat Prod Resour. 2018; 9(2): 85-96.

[16] Kumar GP, Khanum F. Neuroprotective potential of phytochemicals. Pharmacogn Rev. 2012; 6(12):81-90. [CrossRef]

[17] Jarald E, Joshi S, Jain D, Edwin S. Biochemical evaluation of the hypoglycemic effects of extract and fraction of Cassia fistula linn. in alloxan-induced diabetic rats. Indian J Pharm Sci. 2013; 75(4): 427-434.

[18] Gopalasatheeskumar K, Ariharasivakumar G, Kalaichelvan VK, Sengottuvel T, Sanish Devan V, Srividhya V. Antihyperglycemic and antihyperlipidemic activities of wild musk melon (Cucumis melo var. agrestis) in streptozotocin-nicotinamide induced diabetic rats. CHM. 2020; 12: 399-405. [CrossRef]

[19] Deguchi Y, Miyazaki K. Antihyperglycemic and antihyperlipidemic effects of guava leaf extract. Nutr Metab. 2010; 7(9); 1-10. [CrossRef]

[20] Demerdash FM, Yousef MI, Naga NI. Biochemical study on the hypoglycemic effects of onion and garlic in alloxaninduced diabetic rats. Food Chem Toxicol. 2005; 43: 57-63.

[21] Pirart J. Diabetes Mellitus and its Degenerative Complications: A Prospective Study of 4,400 Patients Observed Between 1947 and 1973. Diab Care. 1978; 1: 168-188. [CrossRef]

[22] Janes K, Neumann WL, Salvemini D. Anti-superoxide and anti-peroxynitrite strategies in pain suppression. Biochim Biophys Acta. 2012; 1822(5): 815-821. [CrossRef]

[23] Rodica P, Andrew JMB, Eva LF, Vera B et al. Diabetic Neuropathy: A Position Statement by the American Diabetes Association. Diab Care. 2017; 40: 136-154. [CrossRef]

[24] Hoybergs YM, Biermans RL, Meert TF. The impact of bodyweight and body condition on behavioral testing for painful diabetic neuropathy in the streptozotocin rat model. Neurosci Lett 2008; 436: 13-8. [CrossRef]

[25] Guyue Z, Hui F, Yukai L, Jing X, Dandan Z, Yanan S, Lei Z, Zhang. Neuroprotective Effect of Astragalus Polysacharin on Streptozotocin (STZ)-Induced Diabetic Rats. Med Sci Monit. 2019; 25: 135-141.

[26] Reed TT. Lipid peroxidation and neurodegenerative disease. Free Radic Biol Med. 2011; 51(7): 1302-19. [CrossRef] 
[27] Sivakumar G, Gopalasatheeskumar K, Gowtham K, Sindhu E, Akash Raj K, Rajaguru B, Sriram K, Kalaichelvan VK. Phytochemical analysis, Antioxidant and Antiarthritic activities of different solvent extract of Aegle marmelos L. unripe fruit. Res J Pharm Technol. 2020; 13(6): 2759-2763. [CrossRef]

[28] Uma B, Radha Y, Pophale P,Mandar Z, R.S.Somani. Study of CNS depressant and behavioral activity of an ethanol extract of Achyranthes Aspera (Chirchita) in mouse model. Ann Neurosci. 2011; 8: 44 - 47.

[29] Devi RR, Aruna K, Raja S. The Effect of Biophytum sensitivum Extract Against the Behavioral Changes Induced by 1-Methyl-4-Phenyl-1,2,3,6- Tetrahydropyridine (MPTP) in mice. Pharm Sci \& Res. 2016; 8(12): 1345-1348.

[30] Schleyerbach R. Analgesic, anti-inflammatory, and anti-pyretic activity. In Vogel HG editor. Drug discovery and evaluation of pharmacological assays. 2nd ed. Germany: Springer. 2002.

[31] Nayak SS, Pattabiraman TN. A new colorimetric method for the estimation of glycosylated hemoglobin. Clin Chim Acta. 1981; 109(3): 267-274. [CrossRef]

[32] Reitmann S, Frankel S. A colorimetric method for the determination of serum oxaloacetic and glutamic pyruvate transminases. Am J Clin Pathol. 1957; 28: 56-63. [CrossRef]

[33] Dilip Kumar P. Determination of Brain Biogenic Amines in Cynodon Dactylon Pers. and Cyperus Rotundus L. Treated Mice. IJPPS. 2009; 1(1):190-197.

[34] Raju TR, Kutty BM, Sathyaprabha TN, Shankarnarayana Rao BS. Brain and behavior. National Institute of Mental Health and neurosciences, Bangalore. 2004; 134-138.

[35] Lowry OH, Rosebrough NJ, Farr AL, Randall RJ. Protein measurement with the Folin phenol reagent. J Biol Chem. 1951; 193: 265-275.

[36] Ellman GL. Tissue sulphydryl groups: Archives in biochemistry and biophysics. Arch Biochem Biophys. 1959; 82(1): 70-77. [CrossRef]

[37] Yuvaraja K R, Santhiagu A, Jasemine S, Gopalasatheeskumar K. Hepatoprotective activity of Ehretia microphylla on paracetamol induced liver toxic rats. Journal of Research in Pharmacy. 2021; 25(1): 89-98. Doi: $10.35333 /$ jrp.2021.286

[38] Okhawa H, Ohishi N, Yagi. Assay for lipid peroxidase in animal tissue by thiobarbituric acid reaction. Anal Biochem. 1979; 95: 35-38. [CrossRef]

[39] Boopathi T, Gopalasatheeskumar K, Ariharasivakumar G. Exploration of anti-parkinson activity of aqueous extract of Barleria prionitis with antioxidant potential in MPTP and rotenone induced parkinson rat models. IJBPAS. 2020; 9(9): 2102-2111.

[40] Arzumand ARA, Moshfekus S, Nazım UA, Abul H, Sitesh Chandra B. Anti-diarrheal activity and acute toxicity of methanolic bark extract of Adenanthera pavonina linn (fabaceae) and its elemental composition. Turk J Pharm Sci. 2013; 10(2): 263-272. 